\title{
BUDIDAYA JAMUR TIRAM DENGAN MEDIA KULIT BUAH KOPI UNTUK PELUANG USAHA BAGI WANITA TANI DI KELURAHAN TALANG ULU KABUPATEN REJANG LEBONG
}

\author{
Irma Badarina ${ }^{\left.1^{*}\right)}$, Nadrawati ${ }^{2}$, dan Endang Sulistyowati ${ }^{1}$ \\ ${ }^{1}$ Program Studi Produksi Ternak Fakultas Pertanian Universitas Bengkulu \\ ${ }^{2}$ Program Studi Ilmu Hama dan Penyakit Tanaman Fakultas Pertanian Universitas Bengkulu \\ *)Email :irmabadarina@unib.ac.id
}

\begin{abstract}
ABSTRAK
Kelurahan Talang Ulu Kabupaten Rejang Lebong Bengkulu merupakan salah satu desa dengan tipe agraris yaitu perkebunan kopi. Pendapatan rumah tangga sangat bergantung pada kestabilan harga kopi. Sekitar 50\% rumah tangga berstatus Masyarakat berpenghasilan Rendah (MBR). Kegiatan berkebun/mengurus ladang sebagian besar dilakukan oleh kaum bapak (laki-laki). Sementara para $\mathrm{ibu/wanita} \mathrm{tani} \mathrm{hanya} \mathrm{mengurus} \mathrm{rumah} \mathrm{tangga.} \mathrm{Curahan} \mathrm{waktu} \mathrm{wanita} \mathrm{tani} \mathrm{untuk} \mathrm{melakukan} \mathrm{aktivitas} \mathrm{di}$ luar kegiatan mengurus rumah tangga masih cukup memungkinkan. Setelah urusan domestik rumah tangga selesai maka wanita tani dapat melakukan aktivitas lain yang bertujuan untuk menambah penghasilan keluarga. Salah satunya adalah usaha budidaya jamur tiram putih (Pleurotus ostreatus). Budidaya jamur tiram putih cukup mudah dan murah. Media tumbuh dapat berasal dari limbah kulit kopi yang banyak terdapat di lokasi. Kegiatan PPM ini bertujuan untuk memberikan pelatihan budidaya jamur tiram dengan media kulit buah kopi bagi ibu-ibu tani di Kelurahan Talang Ulu Kabupaten Rejang Lebong Bengkulu. Metode yang dilakukan yaitu Penyuluhan dan Praktik langsung budidaya jamur tiram. Demplot rumah jamur didirikan sebagai tempat ibu-ibu belajar merawat jamur dan berbisnis jamur. Melalui kegiatan ini pengetahuan ibu-ibu tani menjadi bertambah. Budidaya jamur tiram menjadi peluang usaha tanpa mengganggu pekerjaan utama ibu-ibu mengurus rumah tangga. Animo ibu-ibu tani peserta pelatihan cukup baik ditandai dengan terbentuknya kelompok usaha jamur tiram dan keinginan untuk menanam modal sendiri untuk mendirikan rumah jamur tiram.
\end{abstract}

Kata Kunci : jamur tiram, kulit buah kopi, peluang usaha, wanita tani

\section{Oyster Mushroom Cultivation with Coffee Husk Substrate as Business Opportunity for Farmer Women in Talang Ulu Sub-District Rejang Lebong Regency}

Talang Ulu sub-district in Rejang Lebong regency Bengkulu is one of the agriculture-type villages based on coffee plantations. The families' income was really depended on the stability of coffee prices. About $50 \%$ of the families were in the low-income people (LIP) category. Most of the farming activity was done by man. While the women only managed the household. The time for farmer women to do the activity out of the household is still possible. After all the household activities were done, the women farmer could do another activity to get additional income, such as oyster mushroom cultivation. The oyster mushroom cultivation is easy to do and cheap enough. The solid substrate for mushrooms can use the coffee husk that is widely available in the location. This community service activity aimed to train the farmer women in Talang Ulu sub-district about oyster mushroom cultivation. The methods were counseling and direct practice in oyster mushroom cultivation. The mushroom house as a demonstration plot was made for practicing how to take care of and did the mushroom business. This community service activity had increased their knowledge in mushroom cultivation. The oyster mushroom cultivation became the business opportunity being annoying the daily household activity. The animo of the farmer women were good enough that can be seen by making a mushroom cultivation group. They aspire to have their own mushroom business later.

Keywords : Oyster mushroom, coffee husk, business opportunity, farmer women 


\section{PENDAHULUAN}

Jamur tiram merupakan salah satu jenis jamur pangan yang telah lama digunakan tidak hanya karena rasanya, aromanya dan nilai nutrisinya tetapi juga karena komponen obat yang dikandungnya seperti yang diungkapkan dalam literature kuno (Patel et al., 2012). Komponen obat yang dikandung oleh jamur memiliki beberapa gambaran farmakologi seperti sebagai activator metabolik, mencegah/mengontrol intoksikasi dan infeksi bakteri/virus, membantu keseimbangan system kekebalan tubuh dan immunomodulasi, dan sebagai anti oksidan (Wong et al., 2011; Martins et al., 2011). Oleh karena itu mengkonsumsi jamur tiram sangat baik untuk kesehatan.

Budidaya jamur tiram cukup mudah dan murah untuk dilakukan. Jamur tiram dapat tumbuh dengan mudah pada sejumlah besar jenis substrate terutama dari bahan lignoselulosik (limbah kehutanan dan pertanian) dengan input minimum (Gassara, 2010; Sanchez, 2010). Jamur $P$. Ostreatus tergolong white rot fungi yang mampu mendegradasi lignin karena memproduksi enzim ligninolitik ekstra selular seperti laccase, lignin peroxidase and Mn peroxidase (Perwitasari et al., 2018). Media yang umum digunakan adalah serbuk gergajian kayu. Selain itu limbah pertanian seperti kulit buah kopi yang merupakan limbah dari penggilingan buah kopi untuk mendapat biji kopi dapat dijadikan alternative media tumbuh jamur. Limbah kulit buah kopi cukup berlimbah di Rejang Lebong yang merupakan sentra penghasil kopi di Provinsi Bengkulu.

Penggunaan kulit buah kopi sebagai substrate padat untuk budidaya jamur tiram putih dapat dilakukan karena kaya akan bahan organic (Badarina et al., 2013). Kabupaten Rejang Lebong merupakan sentra penghasil kopi di Provinsi Bengkulu. Kulit buah kopi sebagian besar masih belum dimanfaatkan (masih dibuang atau dibakar). Pengolahan buah kopi sebagian besar dengan metode pengeringan dibawah sinar matahari. Kemudian digiling dan dihasilkan biji kopi serta kulit buah kopi. Kulit buah kopi dihasilkan $\pm 21.5 \%$ dari berat buah kopi. Kabupaten Rejang Lebong tahun 2020 memiliki luas areal kebun kopi mencapai 23.000 hektare dengan jumlah produksi mencapai 17.982,7 ton/tahun (Anonimous, 2020). Dari jumlah ini diperkirakan akan dihasilkan kulit buah kopi sebesar 3.866,3 ton/tahun. Tentu sangat bermanfaat bila limbah ini diolah antara lain menjadi media tumbuh jamur tiram.

Kelurahan Talang Ulu dari data profil kelurahan termasuk dalam kecamatan Curup Timur Kabupaten Rejang Lebong. Luas wilayahnya 266,95 ha dan luas pemukiman 33,52ha termasuk berukuran sedang. Penduduk kelurahan Talang Ulu sebagian besar berasal dari suku asli Rejang. Berdasarkan kegiatan pokok yang dilakukan mayoritas penduduk memiliki tipologi agraris yaitu kebun kopi. Pendapatan utama berasal dari penjualan kopi dan atau sayuran. Posisi geografi Kelurahan Talang Ulu berada diperlintasan jalan Bengkulu-Lubuk Linggau sehingga aktivitas perekonomian/perdagangan cukup berkembang. Sebagaimana umumnya daerah agraris, maka pendapatan sangat bergantung pada kestabilan harga kopi dan sayuran.

Jumlah penduduk Kelurahan Talang Ulu sebanyak 2504 jiwa dengan jumlah rumah tangga sebanyak 604 rumah tangga. Dari jumlah rumah tangga ini sebanyak 302 (50\%) rumah tangga merupakan masyarakat berpenghasilan rendah (rumah tangga MBR). Hal ini karena luas areal kebun kopi yang dimiliki kurang dari 2 ha. Berdasarkan jenis kelamin, jumlah laki-laki 1275 jiwa dan perempuan 1229 jiwa. 
Website. http://hilirisasi.lppm.unand.ac.id e-ISSN: 2621-7198

Peranan perempuan dalam keluarga tani umumnya sebagai ibu rumah tangga dengan tugas keseharian adalah mengurus keluarga di rumah. Kegiatan berkebun sebagian besar dilakukan oleh kaum laki-laki. Curahan waktu wanita tani dalam melakukan aktivitas diluar kegiatan mengurus rumah tangga masih cukup memungkinkan. Setelah urusan domestik rumah tangga selesai dilakukan yaitu memasak pada pagi hari, mencuci pakaian, membersihkan rumah dan mempersiapkan anak-anak ke sekolah, maka wanita tani dapat melakukan aktivitas lain yang bertujuan untuk menambah penghasilan keluarga antara lain usaha budidaya jamur tiram.

Usaha budidaya jamur tiram putih cukup menjanjikan. Hal ini karena pangsa pasar masih terbuka lebar. Minat masyarakat untuk mengkonsumsi jamur tiram cukup baik karena jamur telah dikenal masyarakat sebagai makanan yang enak dan baik untuk kesehatan. Berlatar belakang hal tersebut diatas, kegiatan ini bertujuan untuk memberikan pelatihan budidaya jamur tiram dengan memanfaatkan limbah kulit buah kopi. Budidaya jamur tiram ini dapat menjadi peluang usaha bagi ibu-ibu tani untuk menambah income keluarga.

\section{METODOLOGI}

Metode pelaksanaan kegiatan ini yaitu penyuluhan dan praktek budidaya jamur tiram. Kegiatan ini dilaksanakan selama lebih kurang 4 bulan (Bulan Juli 2020Oktober 2020). Kegiatan ini dilakukan di rumah salah seorang warga. Alat-alat yang dibutuhkan yaitu rumah/kumbung jamur, sekop, terpal plastik, plastik baglog, karet, cincin, potongan kertas, kompor gas, drum bekas, bayclin dan sudip. Bahan-bahan yang diperlukan yaitu kulit buah kopi, serbuk gergaji, dedak padi, air bersih, kapur dan bibit jamur tiram(F2). Rumah/kumbung jamur dibuat secara sederhana yaitu dari bambu.

Metode dan komposisi substrat mengadopsi tehnik Badarina et al. (2013). Komposisi substrat terdiri atas $82.5 \%$ serbuk gergaji atau kulit buah kopi, $15 \%$ dedak padi, $1.5 \%$ gips dan $1.0 \% \mathrm{CaCO}_{3}$. Air bersih ditambahkan sebanyak $60-65 \%(\mathrm{v} / \mathrm{w})$. Kadar air dikatakan cukup bila adonan di kepal membentuk gumpalan tetapi mudah hancur kembali. Semua bahan dicampurkan dan dikomposkan selama 24 jam.

Sebanyak 1500gram campuran dimasukkan ke dalam kantong propylene (baglog). Kantong baglog diikat bagian ujungnya dengan memasukkan kapas ke dalam cincin. Kantong disterilkan pada suhu $90-100^{\circ} \mathrm{C}$ selama 5 jam dengan memasukkan semua baglog dalam drum.Setelah dingin (lebih kurang 12 jam), masing-masing kantong diinokulasi (menanam bibit jamur). Inokulasi dilakukan dengan cara membuat lubang dibagian tengah media tanam melalui cincin yang tertanam dengan bantuan kayu berdiameter $2 \mathrm{~cm}$. Kedalaman lubang sekitar $10 \mathrm{~cm}$ dan ke dalam lubang dimasukkan bibit. Kemudian ditutup dengan kapas.

Kantong yang telah diinolukasi bibit jamur kemudian ditempatkan dalam ruang inkubasi/kumbung jamur pada suhu $22-28^{\circ} \mathrm{C}$ dan kelembaban relatif $60-80 \%$ selama 45 hari periode inkubasi.Baglog akan dipenuhi oleh miselium jamur. Primordia jamur akan tumbuh 45 hari setelah inokulasi bibit. Pemanenan tubuh buah jamur dapat dilakukan setelah lima hari munculnya primordia tubuh buah. Pemanenan jamur dilakukan dengan cara memegang tangkai jamur dan memutarnya. Hasil panen selanjutnya ditimbang. Metode pembuatan media baglog untuk budidaya jamur dapat 
dilihat pada bagan berikut. Media yang dibuat adalah media yang berasal dari kulit buah kopi dan serbuk gergajian kayu.

Selama berlangsungnya kegiatan pelatihan dilakukan kegiatan pemeliharaan, pengamatan dan pencatatan yaitu untuk mengetahui jumlah produksi dan lamanya produksi. Pemeliharaan berupa melakukan penyiraman lantai dan penyemprotan media dengan menggunakan spray untuk menjaga kestabilan kelembaban dan suhu di dalam rumah jamur. Hal ini dilakukan dua kali sehari dan untuk musim panas dapat tiga kali sehari. Kondisi lingkungan ideal adalah RH $65-80 \%$ dan $23-30^{\circ} \mathrm{C}$.

Pencatatan dilakukan berupa jumlah produksi dan hasil penjualan produk sehingga dapat memperkirakan jumlah income (keuntungan usaha). Kegiatan pelatihan ini dikatakan berhasil, jika terjadi perubahan tingkah laku peserta pelatihan dari segi pengetahuan, keterampilan dan keinginan untuk melakukan budidaya secara mandiri (dengan modal sendiri). 
Website. http://hilirisasi.lppm.unand.ac.id

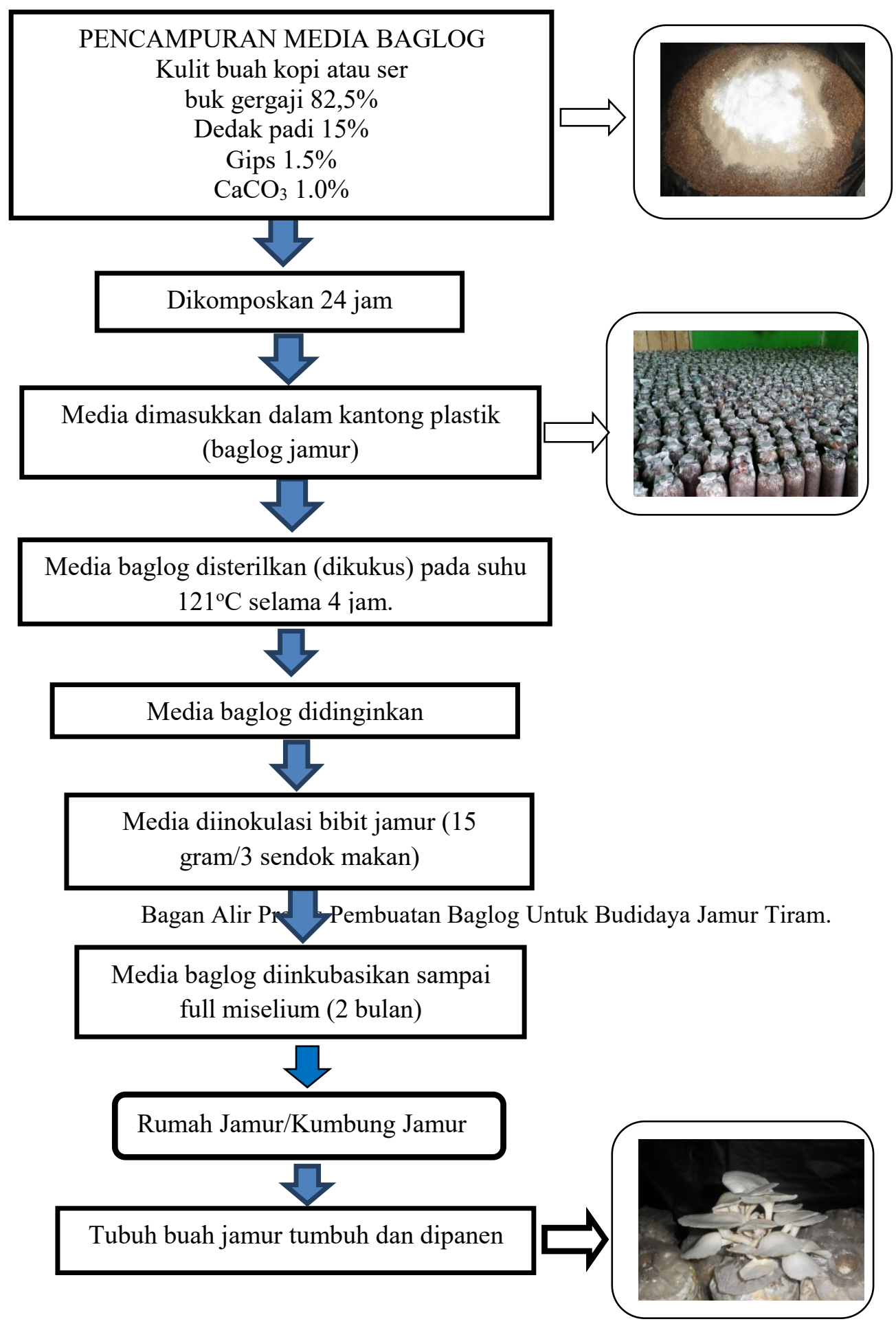




\section{HASIL DAN PEMBAHASAN}

\section{Sosialisasi dan Penyuluhan}

Pelaksanaan kegiatan diawali dengan sosialisasi program bersama dengan Bapak Lurah Talang Ulu dan ibu-ibu wanita tani. Agenda acara sosialisasi ini adalah penyusunan rencana pelaksanaan kegiatan yaitu pembuatan rumah jamur (kumbung jamur), penyuluhan budidaya jamur, praktek budidaya jamur dan pemeliharaan baglog jamur. Setelah kegiatan sosialisasi ini terbentuk kelompok usaha jamur tiram yang beranggotakan ibu-ibu yang hadir pada acara sosialisasi program. Penyuluhan budidaya jamur tiram dihadiri oleh ibu-ibu rumah tangga tani. Materi yang diberikan berupa manfaat konsumsi jamur tiram dan teori budidayanya.

Rumah jamur/kumbung jamur dibuat dengan ukuran 3x4 meter dan tinggi 2 meter. Bahan dinding terbuat dari bambu sedangkan atap terbuat dari seng. Rak jamur dibuat dari kayu dan bilah bambu. Rumah jamur ini berkapasitas sekitar 1000 baglog. Lantai kumbung dari tanah. Pemilihan bahan pembuat bangunan mempengaruhi kelembaban dan suhu optimum dalam budidaya jamur tiram putih. Dinding yang terbuat dari gedeg atau bambuakan mengatur sirkulasi udara secara terus menerus dan akan menambah suasana lembab dalam kumbung.

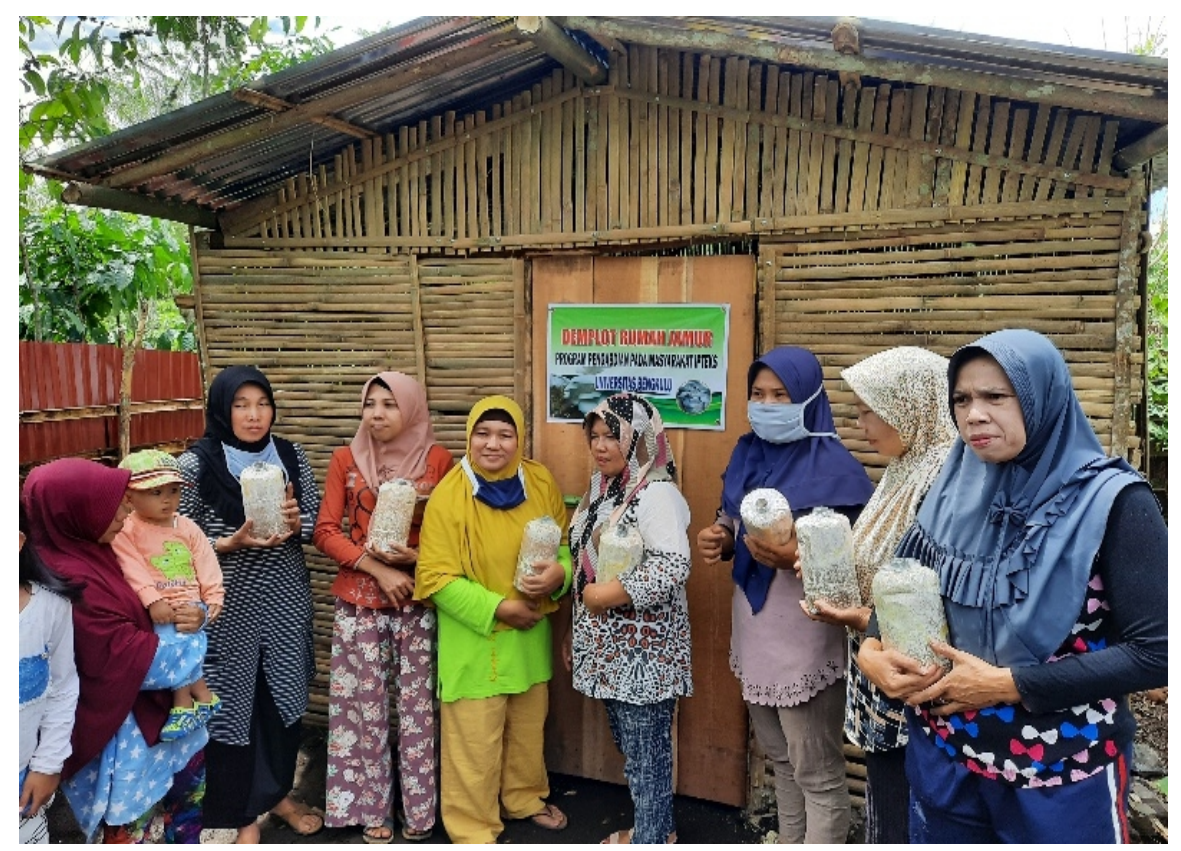

Gambar 1. Bersama ibu-ibu tani di depan rumah jamur

\section{Praktek Budidaya Jamur Tiram}

Praktik budidaya dilakukan mulai dari proses pencampuran bahan-bahan, pengomposan, pembuatan baglog (memasukkan bahan ke dalam kantong plastic), sterilisasi media, inokulasi (penanaman bibit jamur), proses pertumbuhan miselium (inkubasi), perawatan kumbung jamur, pemanenan tubuh buah jamur dan pencatatan jumlah produksi dan penjualan jamur. 
Website. http://hilirisasi.lppm.unand.ac.id e-ISSN: 2621-7198

Praktek pembuatan baglog jamur telah diproduksi 250 baglog jamur. Dari jumlah ini terdapat media baglog yang terkontaminasi $( \pm 20 \%)$ yang ditandai adanya koloni berwarna hijau tua. Kontaminasi ini mengakibatkan pertumbuhan miselium jamur tiram terhambat bahkan mati yang ditandai dengan tidak adanya pertambahan panjang miselium. Diduga koloni ini adalah Trichoderma sp. yang merupakan salah satu kontaminan yang sering menyerang P.ostreatus (Sudarma dkk., 2015). Beberapa factor diduga mejadi penyebab kontaminasi ini yaitu kondisi kurang aseptis saat inokulasi. Atau sterilisasi yang kurang sempurna karena kantong-kantong baglog terlalu rapat ketika didalam drum sterilisasi. Jamur pengkontaminan ini sering terbawa lewat udara dan masuk ketika inokulasi.

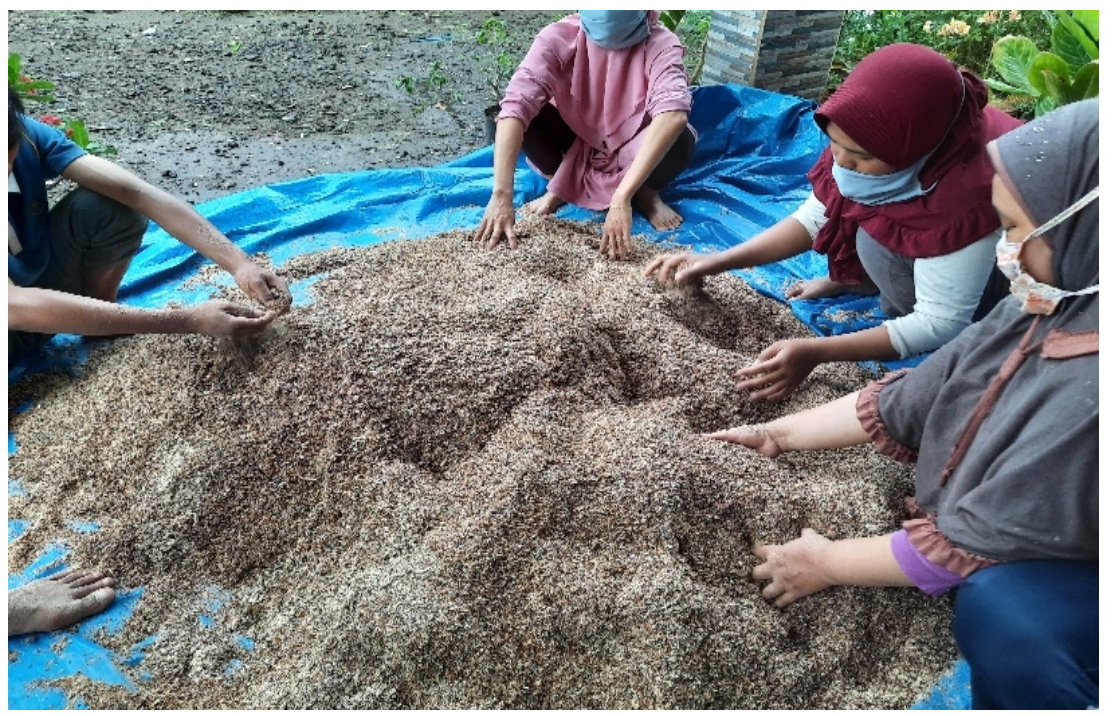

Gambar 2. Praktik budidaya jamur tiram.

Setelah lebih kurang 40 hari baglog sudah mulai fullmycellium dan pada usia 55 hari mulai menghasilkan tubuh buah jamur. Hal ini sejalan dengan Ginting dkk. (2013) yang melaporkan rataan waktu munculnya tubuh buah setelah hari inokulasi pada kayu sengon adalah \pm 50 hari. Berat rata 2 tubuh buah pada panen pertama sekitar 150 gram perbaglog. Pada panen berikutnya berat tubuh buah ini menurun menjadi \pm 100 -125 gram. Interval tumbuh jamur \pm 2 minggu.

\section{Analisis Ekonomi}

Perkiraan analisis ekonomi usaha jamur dilakukan dengan cara sebagai berikut. Harga per kilo jamur tiram segar adalah Rp. 20.000,-. Diperkirakan modal untuk membuat baglog ukuran 1.5 kilogram adalah Rp. 1200,-. Satu baglog jamur dapat berproduksi selama 4 bulan (umur produktif) dengan total produksi $0.4 \mathrm{~kg}$ sampai 0.5 $\mathrm{kg}( \pm 30 \%$ dari beratmedia). Sehingga income selama 4 bulan per baglog jamur adalah $0,5 \mathrm{~kg}$ x Rp. $20.000=$ Rp. 10.000 dikurang Rp. 1200,- = Rp. 8800 atau per bulan Rp.2200 untuk satu baglog jamur. Sehingga bila petani memiliki skala usaha 500 baglog maka mendapat income Rp. 1.100 .000 (Rp.2200 x 500 baglog) (Satu juta seratus ribu rupiah) per bulan. Keuntungan ini akan semakin besar bila skala usaha meningkat. Perhitungan tersebut dengan asumsi tenaga kerja sendiri dan lahan sendiri. 
Dengan demikian bahwa ibu-ibu wanita tani akan mendapat income Rp.1.100.000 setiap bulan dengan memiliki 500 baglog jamur tiram selama 4 bulan.

Kegiatan usaha jamur tiram pada program ini telah menjadi incubator usaha bagi ibu-ibu peserta. Animo ibu-ibu untuk mendirikan usaha jamur tiram sendiri terlihat dari keinginan mereka meneruskan usaha dengan modal sendiri. Keinginan ini tentu timbul karena teknologi budidaya jamur tiram ini cukup mudah untuk diterapkan. Hal ini sesuai dengan Prasetyowati (2017) yang melaporkan bahwa kemudahan penerapan teknologi pertanian membangkitkan motivasi wanita tani untuk mengadopsi teknologi tersebut. Selain itu motivasi untuk meneruskan usaha jamur tiram ini dikarenakan pemasaran jamur cukup baik yang diukur dari jumlah permintaan jamur dari demplot jamur cukup banyak. Hal ini tentu menjadi tantangan dan peluang untuk mengembangkan usahanya. Suryani dkk. (2017) menyatakan bahwa factor eksternal pemasaran, dukungan keluarga, dukungan kelompok dan sarana prasarana berpengaruh nyata terhadap keberlanjutan pengelolaan teknologi pengelolaan lahan pekarangan. Pembinaan teknologi kepada wanita tani dapat diterapkan pada kegiatan usaha tani mereka dengan tujuan memperoleh pendapatan yang lebih baik.

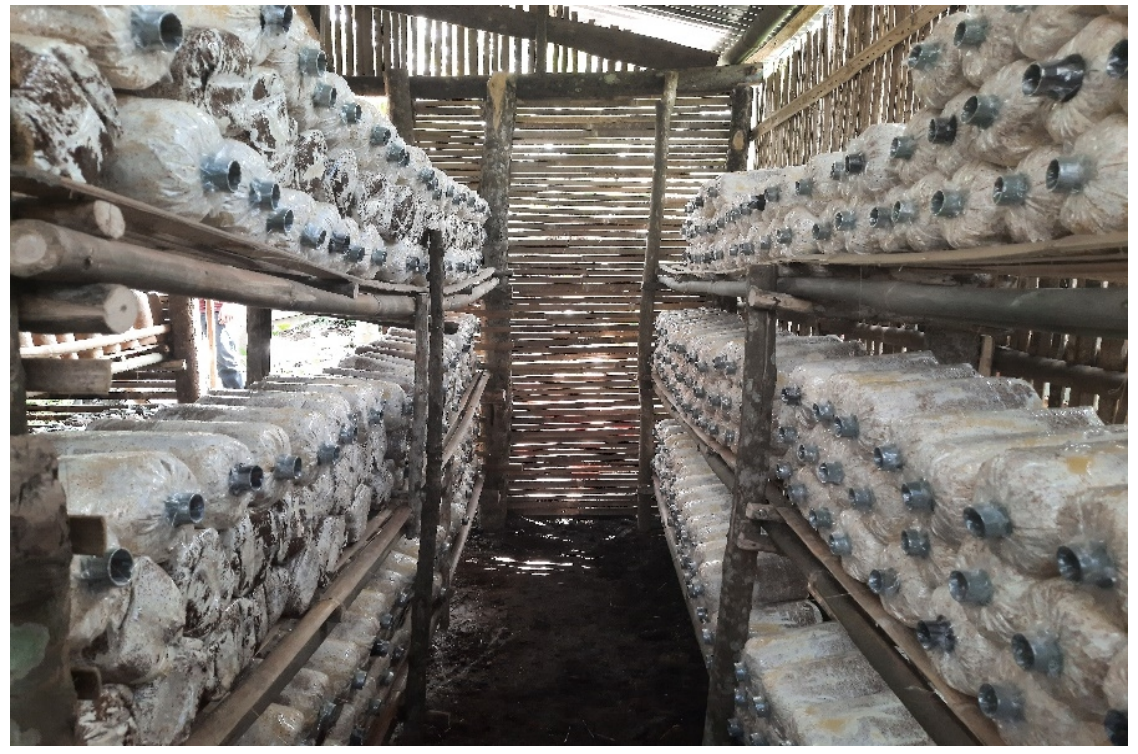

Gambar 3. Baglog jamur siap produksi

\section{KESIMPULAN DAN SARAN}

Kegiatan ini telah menambah pengetahuan dan keterampilan ibu-ibu tani peserta program di Kelurahan Talang Ulu kab Rejang Lebong tentang budidaya jamur tiram. Animo ibu-ibu tani peserta program ini cukup baik yang ditandai dengan kehadiran peserta dari awal sampai akhir kegiatan serta keinginan untuk membuat rumah jamur sendiri (modal sendiri). Adapun saran dari program ini adalah kesinambungan program yaitu kegiatan pengolahan jamur tiram menjadi bentuk olahan (produk olahan). Selain itu usulan pendanaan yang lebih besar untuk menjadikan 
Kelurahan Talang Ulu sebagai desa Wisata Petik Jamur Tiram sebagaimana cita-cita yang diungkapkan oleh ibu-ibu tani kepada Tim Pengabdi.

\section{UCAPAN TERIMAKASIH}

Bersama ini diucapkan terima kasih kepada Lembaga Penelitian dan Pengabdian Kepada Masyarakat Universitas Bengkulu yang telah memberikan bantuan dana pengabdian masyarakat dengan nomor kontrak : 2374/UN30.15/AM/2020 Program PPM Berbasis Ipteks.

\section{DAFTAR PUSTAKA}

Anonimous. 2020. Produktivitas Kopi Rejang Lebong di atas Nasional. https://bengkulu.antaranews.com/berita/95330/produktivitas-kopi-rejanglebong-di-atas-nasional. Diakses 15 April 2020.

Badarina I, Evvyernie D, Toharmat T, Herliyana EN and Darusman LK. 2013. Nutritive value of coffee husk fermented with Pleurotus ostreatus as Ruminant Feed. Med. Pet. Vol 36 No.1 : 58-63

Gassara F, Brar SK, Tyagi RD, Verma M \& Surampalli RY (2010). Screening of agroindustrial wastes to produce ligninolytic enzymes by Phanerochaete chrysosporium. Biochemical Engineering Journal 49(3), 388- 394

Ginting, AR, Herlina N, Tyasmoro SY. 2013. Studi pertumbuhan dan produksi jamur tiram putih (Pleurotus ostreatus) pada media tumbuh gergaji kayu sengon dan bagas tebu. Jurnal Produksi Tanaman Vol. 1 No. 2 (hal 17-24).

Martins S, Mussatto SL, Martinez-Avilla G, Montanez-Saenz J, Aguillar CN, Teixeira JA. 2011. Bioactive phenolic compounds: Production and extraction by solidstate fermentation. A review. Biotechnology Advances. 29: 365-373. doi: 10.1016/j.biotechadv.2011.01.008.

Patel Y, Naraian R, Singh VK. 2012. Medicinal properties of Pleurotus species(Oyster mushroom): A review. World J. Fungal and Plant Biol. 3(1):01-12.

Perwitasari U, Dimawarnita F and Ratnakomala S. Optimization of ligninolytic enzyme production from Pleurotus ostreatus medium waste production using surface response methodology. Menara Perkebunan 2018, 86(1), 29-37. DOI: http://dx.doi.org/10.22302/iribb.jur.mp.v1i1.278 
Prasetyowati, RE. 2017. Faktor-faktor yang mempengaruhi peran wanita tani dalam penerapan teknologi pengelolaan tanaman terpadu pada usahatani jagung di Kecamatan Pringgabaya Kabupaten Lombok Timur. Journal Ilmiah Rinjani_Universitas Gunung Rinjani Vol. 5 No. 1 Tahun 2017. Hal : 59-67.

Sánchez C.2010. Cultivation of Pleurotus ostreatus and other edible mushrooms. Applied microbiology and biotechnology 85(5), 1321- 1337

Sudarma, IM, Puspawati NM, Purmidhi NN, Yuliadhi KA, Suniti NW, Bagus IGN, Wijaya IN dan Widaningsih D. 2015. Keragaman dan daya hambat spora tular udara yang mengkontaminasi media baglog Jamur Tiram putih (Pleurotus ostreatus (Jacq. Ex Rr) Kummer). Jurnal Agrotrop. 5 (2) : 150 - 160

Suryani, A, Fatchiya, A., \& Susanto, D. 2017. Keberlanjutan Penerapan Teknologi Pengelolaan Pekarangan oleh Wanita Tani di Kabupaten Kuningan. Jurnal Penyuluhan, 13(1), 50-63. https://doi.org/10.25015/penyuluhan.v13i1.14641

Wong KH, Lai CKM, Cheung PCK. 2011. Immunomodulatory activities of mushroom sclerotial polysaccharides. Food Hydrocolloids. 25:150-158. 